ENTREPRENEURSHIP AND SUSTAINABILITY ISSUES

ISSN 2345-0282 (online) http://jssidoi.org/jesi/ 2020 Volume 8 Number 1 (September) http://doi.org/10.9770/jesi.2020.8.1(72)

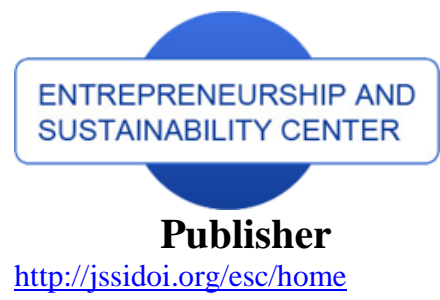

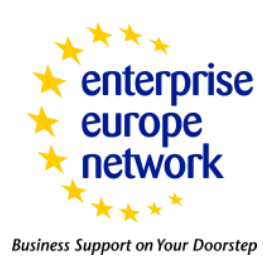

CASPA

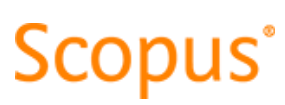

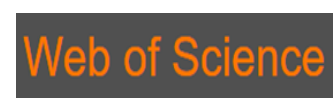

Clarivate
Analytics

\title{
JAPAN'S DIGITAL ADVANCE POLICY TOWARDS PERFORMANCE IN MULTILATERAL ASEAN'S INNOVATION BUSINESS*
}

\author{
Somnuk Aujirapongpan ${ }^{1}$, Yaninee Songkajorn ${ }^{2}$, Supit Ritkaew ${ }^{3}$, Sirichai Deelers ${ }^{4}$ \\ ${ }^{1,2,3}$ School of Management, Walailak University, Nakhon Si Thammarat, 80160, Thailand \\ ${ }^{4}$ Faculty of Management Science, Silpakorn University, Petchaburi, 76120, Thailand \\ E-mails: ${ }^{1}$ asomnuk@wu.ac.th (Corresponding author); ${ }^{2}$ yaninee.so@wu.ac.th ; ${ }^{3}$ supit.ritkaew@gmail.com; \\ 노irichai@ms.su.ac.th
}

Received 18 March 2020; accepted 18 July 2020; published 30 September 2020

\begin{abstract}
This paper examines issues relating to Japan's digital advance policy (DAP) for ASEAN countries during the period 2015 2019, which aimed at broadening the spectrum of digital economic growth. The study sought to gain insights into the impacts of respective policies of ASEAN, Japan Council for Science, Technology and Innovation (CSTI), Japanese digital foreign direct investment (FDI), and Japanese enterprises. The study also examined workflow structure processes to explain how Japan's DAP contributes to ASEAN's innovation business. This research is categorized as a reconnaissance study, based on empirical analysis of pertinent existing evidence, complemented by 74 in-depth interviews with key experts from ASEAN, JICA, CSTI and major digital enterprises from 5 ASEAN countries. The findings indicate a need to redirect the innovation business of Japan's DAP as well as ASEAN's innovation business and to enhance their mutual alignment. Four key entry points are proposed: (1) policymakers, (2) private sector businesses, (3) goalkeeper science, and (4) innovative infrastructure. This paper also provides guidelines and support to validate key performance indicators of Japan's DAP in ASEAN countries. The studies how Japan's digital holistic platforms could be transferred to ASEAN countries under the DAP. It also examines the relationship between key performance indicators of Japan's outward FDI in ASEAN digital businesses and growth in ASEAN's innovation business.
\end{abstract}

Keywords: open innovation; entrepreneurship; innovation business; ASEAN; Japan; foreign direct investment

Reference to this paper should be made as follows: Aujirapongpan, S., Songkajorn, Y., Ritkaew, S., Deelers, S. 2020. Japan's digital advance policy towards performance in multilateral ASEAN's innovation business. Entrepreneurship and Sustainability Issues, 8(1), 10811094. http://doi.org/10.9770/jesi.2020.8.1(72)

JEL Classifications: D25, F23, M40, M41, N65

*This research was partially supported by the new strategic research $(P 2 P)$ project, and it also was supported by Institute of Research and Innovation, Walailak University, Thailand. 


\section{ENTREPRENEURSHIP AND SUSTAINABILITY ISSUES}

ISSN 2345-0282 (online) http://jssidoi.org/jesi/

2020 Volume 8 Number 1 (September)

http://doi.org/10.9770/jesi.2020.8.1(72)

\section{Introduction}

Urbanization has historically been both a key driver and a result of national economic development (Bairoch, 1988; Gallup et al., 1999). The relationship between modernization and sustainable economic growth is important, particularly in the context of diffusion of innovations in developing countries. Consequently, digital policies can carry significant direct impacts on sustainable national economic development. In addition, digital economic integration represents a longer-term permanent development rather than a short-term development as asserted by free market fundamentalists (Hankle and Isaak, 2011; Belz et al., 2019). However, the risks associated with technological investment can be high (Martin et al., 2018; Limba et al., 2020).

The rules of digital globalization are set by wealthy countries; they are extremely complex and present significant barriers to entry for developing countries, including those within the ASEAN region.

ASEAN is the world's 7th largest economy, with a combined GDP of USD2.5 trillion. By 2030 it is expected to rise up the rankings to the world's 4th largest economy (Malaysian Global Innovation \& Creativity Center, 2019). Moreover, the economies of six ASEAN Member States (Indonesia, Malaysia, Philippines, Singapore, Thailand, and Vietnam) are all expected to cross the USD 3,000/capita barrier (Asia-Pacific Economic Cooperation, 2018). Recognizing this burgeoning economic expansion among its neighbours, Japan has been actively investing in a wide range of technological innovations, including new innovative institutional modalities to support collaboration and research partnerships among universities, R\&D laboratories across the ASEAN region. Today, key drivers of the global economy face market saturation and limited natural resources (Raghuvanshi and Garg, 2018). Japan itself, with limited natural resources of its own and a rapidly aging population, is highly vulnerable to these challenges to continuing growth. There are indeed a number of emerging signals of crisis in Japan, which if ignored, will slowly lead to a decline in the country's core business and economic growth (Yukawa, 2018). A sustained recovery will require policies that to foster wage growth and technological investment for the future (Okubo, 2019). Hence, investment in ASEAN countries is core to Japan future economic trajectory, as articulated in the country's Digital Advance Policy (DAP) in ASEAN countries.

In recent times, Japan and ASEAN have enjoyed close economic cooperation and growing levels of FDI, particularly in the ASEAN+3 countries (Japan, China and the Republic of Korea) as well as in their respective production networks. Since the 1960s, Japan has become a major investor across the entire Southeast Asia region (Ratna and Sharmar, 2016). However, ASEAN has continued as the main target for Japanese FDI. Japanese enterprises are expanding their operations in ASEAN, establishing subsidiaries, R\&D, production lines, and other business functions. Japan is now the largest investor in the region (METI, 2013). Moreover, in 2019 Japan reclaimed its status as Southeast Asia's top trade partner (Li, 2019). Japan's FDI policies have taken an increasingly long-term view, focusing on development of strategic infrastructure that will drive business growth (Afzal et al., 2018). The focus of FDI is also gradually shifting from the ASEAN-5 countries toward the CLMV countries (Cambodia, Laos, Burma, and Vietnam) (ODI, 2019). Japan's digital policy is positioned with the aim of "advancing partnerships for sustainability" in the ASEAN region, emphasizing cooperation and transfer of skills and technologies to enable their trade partners to prosper in the digital economy.

The purpose of this paper is to explore the success and challenges inherent in Japan's DAP in ASEAN countries, with the aim of ascertaining its broader impact on digital economic growth and implications for the future economic trajectory of ASEAN countries in the digital age. The study began with the main research question: What is the direction of ASEAN's innovation business and DAP? The results of this study show four key entry points are proposed: 1) The policymakers in ASEAN. 2) Private sector. 3) Goalkeeper science of ASEAN member. 4) International authority and innovative infrastructure. This paper also provides guidelines and support to validate key performance indicators of Japan's DAP in ASEAN countries. 


\section{ENTREPRENEURSHIP AND SUSTAINABILITY ISSUES}

ISSN 2345-0282 (online) http://jssidoi.org/jesi/

2020 Volume 8 Number 1 (September)

http://doi.org/10.9770/jesi.2020.8.1(72)

\section{Rationale, background and economic status of ASEAN countries}

\subsection{Rationale: ASEAN's digital economy is accelerating}

Innovation policy has served as the core driver underpinning policies for research, science and technology, with their respective linkages to investment in knowledge creation and economic activity (Berry et. al., 2014). As highlighted by Potts (2016), who extend the use of three concepts of national innovation policy interaction to representing a global strategic engagement with the world correspond to positions of autarky, cooperation or innovation system (EU/OECD approach), and competition or the race for global comparative advantage (USA/East Asia approach). Under autarky (as a state of self-sufficency), national innovation policy has no strategic value, either because of deliberate isolationism (minimizing cross-border trade flows), or because the nation sees itself as sufficiently large, dominant or unique.

There has traditionally been a tendency to focus more on technological process innovation and goods product innovation than on service, solution and business innovation (Windahl, 2015). However, new technologies and innovations are already disrupting and transforming markets, businesses, culture and societies at an everaccelerating pace. A sound understanding of the dynamics of this rapid technological advancement and its wider impacts is therefore urgently needed. How does innovative technological investment create new opportunities and disrupt established innovative business modalities? Businesses are racing to rethink their business models to sustain competitive advantage even as digital markets erode their traditional market share. Innovative business concepts have become essential for new firms to secure investment, identifying and catching the latest wave in emerging market opportunities (Tor et. al., 2018). Technology offers a rich source of market opportunities that provide the necessary incentive for investment. Digital transformation has fundamentally transformed the industrial and business landscape at global as well as national and local levels (Table 1).

These technologies have powered the emergence of new domains in technology and business, including robotics, artificial intelligence, machine learning. data analytics, cloud computing, fintech, energy and the Internet of Things (IoT). Convergence among these enabling technologies opens up a breathtaking array of possibilities with far-reaching consequences for business, society and our cultural identities. Understanding and adapting to digital realities are therefore fundamental to sustain competitive advantage in the digital era. ASEAN's digital business has been increasing fast in recent years and continues to expand, financed both by governments and venture capital, which have focused on building a world-class digital infrastructure.

\subsection{Japan's Foreign Investment of digital business in ASEAN countries}

According to the Government of Japan (2019), Japan is determined to lead global economic growth by promoting technology and innovation, achieving both economic growth and reduction of disparities, and contributing to the development agenda and other global issues with the United Nations Sustainable Development Goals (SDGs) at its main strategies. ASEAN has enjoyed significant investment growth in the innovation and digital economy, including e-commerce, financial technology, digital infrastructure e.g. internet services and data centres (UNCTAD, 2018). Foreign and ASEAN digital multinational enterprises (MNEs) and ICT companies are now increasing attention on the region (Nanterme, 2016). 


\section{ENTREPRENEURSHIP AND SUSTAINABILITY ISSUES}

ISSN 2345-0282 (online) http://jssidoi.org/jesi/ 2020 Volume 8 Number 1 (September) http://doi.org/10.9770/jesi.2020.8.1(72)

Table 1. Digitalization of the global economy

\begin{tabular}{|c|c|}
\hline Digitalization of Global Economy & Context \\
\hline Technology and Innovation & $\begin{array}{l}\text { Technology Innovation related with new technology and emerging } \\
\text { technology. That reflects the business consideration of improving } \\
\text { business value by working on technological aspects of the product } \\
\text { or services. }\end{array}$ \\
\hline Telecommunication & $\begin{array}{l}\text { The exchange of information, voice or data, per time per space by } \\
\text { electronic means. }\end{array}$ \\
\hline Information Technology & $\begin{array}{l}\text { The application of computers and internet to store, retrieve, transmit, } \\
\text { and manipulate data, or information. }\end{array}$ \\
\hline Internet of Things Platforms & $\begin{array}{l}\text { Provides operate diverse business models to cater for the manifold } \\
\text { requirements of the IoT. Includes combines the mobile and internet } \\
\text { network. }\end{array}$ \\
\hline Digital Content & $\begin{array}{l}\text { Digital content (digital media) is any content that exists in the form } \\
\text { of digital data. Includes information that is digitally broadcast, } \\
\text { streamed, or contained in computer files. }\end{array}$ \\
\hline Digital Multinational Enterprises & $\begin{array}{l}\text { Performing activities based on or strictly linked to the internet. } \\
\text { Markets and MNEs are migrating to cyberspace that grows rapidly. }\end{array}$ \\
\hline E-Commerce & $\begin{array}{l}\text { E-commerce is a term for any type of business, or commercial } \\
\text { transaction, that involves the transfer of information across the } \\
\text { Internet. }\end{array}$ \\
\hline Digital Solutions & $\begin{array}{l}\text { A series of a solution provided by a digital marketing agency or } \\
\text { consultant that to establish a successful business and help it grow } \\
\text { online. }\end{array}$ \\
\hline Digital Energy & $\begin{array}{l}\text { The digital energy represents an energy flow that is transparently } \\
\text { measured in real time at a number strategic locations in the energy } \\
\text { grid. }\end{array}$ \\
\hline Digital Health & $\begin{array}{l}\text { Digital health is the convergence of digital technologies with health, } \\
\text { healthcare, living, and society to enhance the efficiency of healthcare } \\
\text { delivery and make medicines more personalized and precise. }\end{array}$ \\
\hline
\end{tabular}

Japan's DAP focuses on three areas: (1) Areas where interdisciplinary opportunities are enlarging; (2) Areas where traditional markets can benefit from innovation; (3) Emerging markets that are attracting investment. Japan has identified several areas with potential to make vast impacts on reducing GHG emissions, including sustainable energy as a fundamental pillar for 'Society 5.0'. R\&D into prioritized technologies will be promoted in the medium-to-long term, while identifying and addressing DAP challenges (Japan Council for Science, Technology and Innovation, 2016). Japan also aims to foster startups in Southeast Asia with venture capital investment (Southeast Asia Tech Investment, 2018). With its population of 267 million, Indonesia is identified as one of Japan's key markets. To succeed and mitigate business risks it is essential to establish business partnerships with leading domestic companies with established supply chain networks (Munshi et. al., 2018). Japanese enterprises and Japanese FDI foster such collaboration. Meanwhile, Thailand's 'Thailand 4.0' initiative aims to incubate digital development to realize its goal that the digital economy will contribute 25 percent of the country's GDP by 2027 (Trinidad, 2018). Thailand 4.0 focuses on three areas: e-commerce, digital infrastructure and the innovation ecosystem, where Japanese companies can contribute through advanced technology via Japan's DAP (JICA, 2018).

To modernize its industry and drive global competitiveness, Malaysia is making efforts to acquire innovation and know-how from overseas companies (Sukma and Soeya, 2015). To attract such businesses, the government has established a Digital Free Trade Zone (DFTZ) and is also supporting domestic start-ups and entrepreneurs 


\section{ENTREPRENEURSHIP AND SUSTAINABILITY ISSUES}

ISSN 2345-0282 (online) http://jssidoi.org/jesi/

2020 Volume 8 Number 1 (September)

http://doi.org/10.9770/jesi.2020.8.1(72)

(GECS, 2017). Japan's DAP aims to achieve a free flow of data with suppliers in digital business and since the early 2000s has strengthened its investment in Cambodia and the Greater Mekong Subregion (Beeson, 2016). The Cambodian government is currently developing an ICT policy with the purpose of providing universal service and access to ICT infrastructure and the broader digital economy (UNCTAD, 2018). According to Japan External Trade Organization (JETRO), Lao People's Democratic Republic recently implemented a national strategy and regulatory framework to foster ICT and the digital economy. The country has mostly applied ASEAN's ICT platform and IoT related frameworks (JETRO, 2018). Laos and Japan are also collaborating to promote expansion of digital financing and cooperation in economic development, reflecting the strengthening of the friendship and trading relationship between the two nations (ASEAN Secretariat, ASEAN FDI database, 2018).

The global competitiveness scores of ASEAN countries shows record levels of Japanese FDI in Myanmar for a second consecutive year. The government of the Union of Myanmar issued an economic policy focusing on investment and human resources development and includes a strategy for digital government (Hsu, 2017). To support this goal, Japan wants to support Myanmar in its human resource development, as well as provide technical assistance and financial support for development of the SME sector (UNCTAD, 2018). Brunei Darussalam has established a long-term road map know as the 'Brunei Vision 2035, which includes the digital sector to diversify the innovation business and includes a strong commitment to training R\&D by Japanese enterprises (World Economic Forum, 2017). Vietnam's unprecedented economic growth has captured the world's attention (Yoshimatsu, 2017). Currently, many Japanese companies are investing in and establishing bases in Vietnam, with support under Japan's DAP (Japan External Trade Organization, 2019). Japanese IT firms are also expanding their investment and operations in Vietnam (Ministry of Vietnam Internal Affairs and Communications, 2019). Recognizing the importance of reliable and sustainable digital infrastructure as an essential economic foundation for growth, Japan is implementing the 'Expanded Partnership for Quality Infrastructure' to provide financing for infrastructure projects across the world by 2021 (World Economic Forum, 2019). The initiative seeks to establish give-and-take accommodations and long-term relationships with partner countries through contributing to their development.

\section{Methodology}

This research paper is based on empirical analysis of pertinent existing evidence and literature covering the period 2015-2019, and was undertaken over a two-year period from August 2018 to April 2019. The study was coordinated with the cooperation of ASEAN, Japan International Cooperation Agency (JICA) and the Japan Council for Science, Technology and Innovation (JCSTI). The study drew on the databases of the Japan Council for Science, Technology and Innovation (CSTI), Japanese digital foreign direct investment (FDI) and included a structured foresight study to explore how Japan's DAP contributes to ASEAN countries and ASEAN's innovation business. The main objective was to gain an understanding of key issues in Japan's digital advancement policy in ASEAN countries, that could be used to support projections for the future growth and competitiveness of ASEAN's innovation business. The literature review was complemented by in-depth expert interviews to gain insight into Japan's DAP and ASEAN in order to answer the research question: "What are the directions of ASEAN's innovation business and DAP?", focusing on relevant policies and the existing dynamic digital economic, business and regional sectors. The interviews used the in-depth interview technique as a qualitative research tool. The main criteria are as follows: 1) Based upon official DAP projects covering the period 2015 to 2019 in ASEAN. 2) Based upon Japanese organizations and companies in ASEAN. 3) Based upon research units of Japan Foreign Direct Investment in ASEAN. 4) Based upon the innovation-related strategies and activities of Japanese digital enterprises in ASEAN.

The study authors conducted 74 interviews between August 2018 and April 2019 (see Table 2 for details), and analyzed 240 official DAP projects covering the period 2015 to 2019. Representatives from a total of 56 wellknown Japanese digital enterprises active in Southeast Asia were also interviewed. From the total 74 interviewees, 
4 (5.40 percent) were officers from ASEAN headquarters in Indonesia and Thailand, 4 (5.40 percent) were from JICA in Thailand, Singapore, Malaysia and Philippines, 3 (4.05 percent) were officers from Japan CSTI. 11 interviewees (14.86 percent) were from research units in Thailand, Singapore and Malaysia, and 52 interviewees (70.27 percent) were staff members from digital enterprises in Singapore, Malaysia, Thailand, Philippines and Vietnam). The scope of the interviews covered Japan's DAP, Japan's FDI outflows, economic trends within the ASEAN community and three main research questions. The average duration of the interviews was approximately 1 hour. The interviewees were senior executive strategists, senior directors, researchers, government officers and head officers in their current projects, selected to provide an appropriate diversity in terms of relevant background, experience, tacit and explicit domain knowledge relevant to the study.

The study also analyzed the innovation-related strategies and activities of several large multinational enterprises (MNEs) in ASEAN (Sahadev and Hoontrakul, 2015). With the entry into force of the ASEAN+3 (Japan, China and the Republic of Korea) Free Trade Agreement, it is now much more viable for firms to enter into technology partnerships and leverage economies of scale through operating at the regional level.

Table 2. Main interviews and 240 official projects

\begin{tabular}{|c|c|c|c|c|c|}
\hline Organization & Interviewee & Percent & Country & Timeframe & $\begin{array}{l}\text { Number of official projects } \\
\text { (Related with DAP) }\end{array}$ \\
\hline ASEAN & 4 & 5.40 & $\begin{array}{l}\text { Indonesia } \\
\text { Thailand }\end{array}$ & $2015-2019$ & 24 \\
\hline JICA & 4 & 5.40 & $\begin{array}{l}\text { Thailand } \\
\text { Singapore } \\
\text { Malaysia } \\
\text { Philippines }\end{array}$ & $2015-2019$ & 52 \\
\hline CSTI & 3 & 4.05 & Japan & $2015-2019$ & 37 \\
\hline Digital Enterprises & 52 & 70.27 & $\begin{array}{l}\text { Thailand } \\
\text { Singapore } \\
\text { Malaysia } \\
\text { Philippines } \\
\text { Vietnam }\end{array}$ & $2015-2019$ & 102 \\
\hline Research Units & 11 & 14.86 & $\begin{array}{l}\text { Thailand } \\
\text { Singapore } \\
\text { Malaysia }\end{array}$ & $2015-2019$ & 25 \\
\hline
\end{tabular}

Japan still leads in Southeast Asia's infrastructure race through Japanese-backed projects in the region's six largest economies (Indonesia, Malaysia, Philippines, Singapore, Thailand and Vietnam). The Asian Development Bank (ADB) estimates that Southeast Asia's economies will need continuing investment in technology and innovation until 2030, in order to maintain momentum and stimulate continuing economic growth. Meanwhile, across all Southeast Asia and by number of projects in 2018, growth pushers in Southeast Asia are moving from resource development and exports to consumer spending, digital business and infrastructure investments (Shimato, 2018). 


\section{Results}

The findings of this study reveals that Japan's DAP in the Southeast Asia focuses on three priority issues: (a) sustainable economic growth by promoting Japanese business and technological investment; (b) adapting to change in the business cycle, and (c) establishing and entering geopolitics in Southeast Asia (Figure 1). ASEAN countries are adopting the concept of innovation and integrating it into national policies; however, such policies often confuse innovation with R\&D and endogenous business. A clear understanding of the dynamics of innovative business policy and innovative business performance is critical to designing and configuring the development of appropriate Science Technology and Innovation (STI) indicators that are relevant to monitor and respond to the dynamics of technological and digital business. Furthermore, it is important that officials do not reduce STI and R\&D (Manyuchi and Mugabe, 2017).

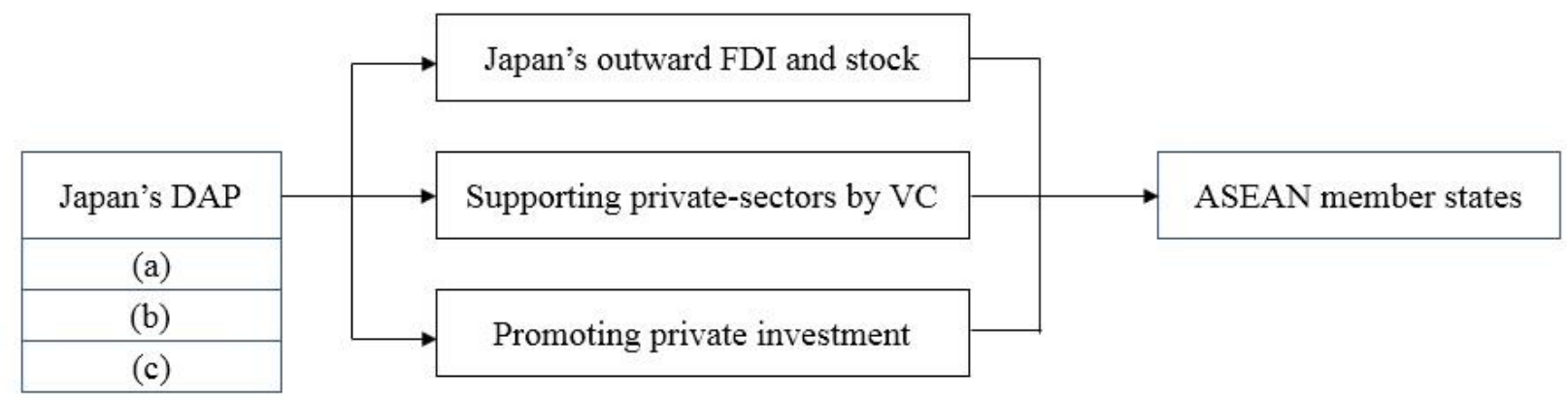

Figure 1. Japan's DAP workflow in ASEAN

Japan, Korea, China, and Singapore offer examples of successful implementation of digital innovation policies, as measured by key performance indicators (Uhm et al., 2018). They have all set and (in different ways) achieved their own goals for innovation by systemically formulating and implementing highly focused and targeted innovation investment policies (Arrow, 1962 and Ambashi, 2018). The key performance indicators for Japan's DAP in ASEAN countries are listed below.

\subsection{ASEAN's innovation business has been developing speedily that go along with Japan's outward FDI, stock and its proportion to ASEAN capacities}

After China and India, ASEAN has the third largest number of Internet users in the world. The region's energetic participation in digital development, joint ventures and promotion of investment in ICT infrastructure are major drivers of this growth. Japan will require the right DAP and regulatory framework to encourage further participation and investment by the private sector. According to Japan's outward financing policy, the increase can be attributed to overall transaction with outward FDI in the international balance of payments and adjustments to accommodate movements such as discrepancies between balance of payment figures and foreign assets.

\subsection{Cross-border venture capital and investment in the digital-social contract in ASEAN is rising}

Cross-border ICT M\&As have risen rapidly, and venture capital investments with exposure to the digital economy result in a particular social contract. Indeed, the very fabric of society is always based on some sort of deal between citizens and the State. As with all transformative innovations, digital innovations can have social 


\section{ENTREPRENEURSHIP AND SUSTAINABILITY ISSUES}

ISSN 2345-0282 (online) http://jssidoi.org/jesi/

2020 Volume 8 Number 1 (September)

http://doi.org/10.9770/jesi.2020.8.1(72)

consequences, for better and for worse. Japanese enterprises are increasing use of M\&A as a means of rapid scaleup, to access new technology and human capital, and expand networks in the ASEAN region.

\subsection{The digital revolution is disrupting and transforming innovation industries, fueled by venture capital}

The venture capital industry is growing rapidly, particularly in Malaysia, Thailand, Singapore and Indonesia, partly driven by expansion in its exposure to the digital economy. Many businesses, particularly delivery of goods and services in ASEAN have innovated their way to success, supported by Japanese venture capital. The digital economy has also generated opportunities to accelerate development by increasing business efficiency and productivity, widening access to new markets, and facilitating participation in global venture capital (GVC). Japanese enterprises are the one of key players as the GVCs. The DAP is broad-reaching, affecting many industries including fintech, retailing, e-commerce, payment systems as well as digital content and digital solutions. Financial institutions, including venture capital and private equity funds, contribute to the digital revolution not only by funding digital initiatives, but also by facilitating access to financial services and support through digital innovations.

\subsection{Social reality creates a new typologies of players}

Diverse stakeholders are all contributing to the development of various components of ASEAN's digital economy, from enabling national policies and incentives, modern ICT infrastructure, private sector R\&D and private capital. Digital enterprises (providing technology and e-commerce) and ICT MNEs (providing digital infrastructure) are active in different segments, including digital value chains, infrastructure, funding and startup incubation. However, the players can also be categorized in terms of their network cohesion. Across the ASEAN region, with a few exceptions domestic companies typically participate through joint ventures with overseas digital MNEs in development of telecommunications infrastructure in the region, which provide the foundation for the digital economy.

Meanwhile, national policy offers a significant enabling tool to support digital ecosystems. They provide a regulatory framework to clarify rules for operation of cross-border enterprises and start-ups, and thus foster subsequent investment, expansion and internationalization. Although the VC industry in ASEAN is still nascent compared to that in China or the United States, opportunities in the region's digital industry are increasingly attracting international firms and supporting the expansion of ASEAN-based funds. The most active VC companies in terms of their digital investments in the region are from ASEAN (mostly in Singapore), China, Japan and the United States.

\section{Contributions}

The strengthening of the DAP process within the ASEAN will be essential to strengthening businesses based on innovation convergence. ASEAN's innovation business should therefore address three interlinked questions as listed below.

\subsection{Is ASEAN heading in the right direction of DAP?}

As a regional bloc, ASEAN strives towards greater consistency and coherence among its member states by advancing the region towards a more connected digital business and facilitating cross-border commerce and investment. ASEAN countries have been energetically advancing and incubating an empowering environment for 


\section{ENTREPRENEURSHIP AND SUSTAINABILITY ISSUES}

ISSN 2345-0282 (online) http://jssidoi.org/jesi/ 2020 Volume 8 Number 1 (September) http://doi.org/10.9770/jesi.2020.8.1(72)

investment in the digital economy. The current study found (a) that ASEAN members have been successfully advancing their digital and telecommunication industries, and are actively promoting private capital investment to drive the transformation towards a digital economy. Most ASEAN members also have articulated and launched enabling policies and incentive programmes relevant to priority industry sectors, and are collaborating to deepen regional integration and cooperation on digital connectivity. Meanwhile, countries have also adapted international policies addressing issues such as taxation of digital cross-border enterprises, skill development, public investment systems, and authorized institutions to stimulate investment in digital industries.

\subsection{Can Japan's integrated digital platforms be transformed to ASEAN member states?}

It is important to understand the differences in capabilities and stage of advancement of digital business sectors across the region. Accordingly, Japan's DAP is based on systemic assessments of the trajectories of national systems and policies. The current study found that Japanese enterprises may be categorized into two main groups: platform providers (e.g. development of digital infrastructure), and users (e.g. technology and innovation businesses). The impacts or influence of Japan's DAP for selected ASEAN member states are summarized in Table 3, and reflect the prevailing stage of advancement of digital readiness and rollout of digital businesses in each country.

As might be expected, the study indicates that Singapore is the only ASEAN member to have reached the 'Evolution Synthesis' stage of innovative development and digital capability. Singapore today has acquired the interdisciplinary skills to achieve global competitiveness through high-tech collaboration with R\&D institutions. Malaysia on the other hand, is categorized in the 'Approximate' stage, with its digital innovation and technological capability at mid- to-high level. Malaysia can cooperate effectively as a partner in technology transformation and in strong technology-based R\&D, supported by DAP. Thailand is classified in the 'Pace' stage, as it still needs interdisciplinary expertise, effective innovation policies and expansion of private sector innovation to drive digital businesses, supported by DAP. Thailand's continuing political uncertainty has posed a major challenge to growth and inward investment, and sharply increasing levels of income inequality are also problematic. However, if Thailand is able to successfully address these issues, it could rapidly be reclassified in the 'Approximate' stage. Indonesia, Philippines, and Vietnam are classified as in the 'Apprentice' phase, characterized by the studying process of digital \& innovation capability. These countries are estimated to have key potential to upgrade their innovation capability as their economies and populations grow. Meanwhile, Vietnam has improved its national education, extending its potential for future leadership. Myanmar, Cambodia, and Lao PDR are in the 'Pre-incubation' stage, which means they still need to establish national infrastructure and essential institutions in order to build up a significant digital and innovation capability. These countries need strong FDI to support these processes. Finally, Brunei Darussalam is in the 'Unique' stage, Brunei has its own economic model, supported by its abundant natural resources. However, Brunei is increasingly aware of the need for transformation through digital innovation. 


\section{ENTREPRENEURSHIP AND SUSTAINABILITY ISSUES}

ISSN 2345-0282 (online) http://jssidoi.org/jesi/ 2020 Volume 8 Number 1 (September) http://doi.org/10.9770/jesi.2020.8.1(72)

Table 3. Consequences of Japan's DAP in ASEAN countries

\begin{tabular}{|c|c|c|c|c|}
\hline COUNTRY & STAGE & ASEAN CONSEQUENCE & SOCIAL CONTRACT & JAPAN DIGITAL FDI AND HOST COUNTRY \\
\hline Singapore & Evolution Synthesis & $\begin{array}{l}\text { Singapore can synthesis the interdisciplinary } \\
\text { to deep technologies, and international } \\
\text { competitiveness in high-tech collaboration } \\
\text { with R\&D and Japan's DAP can } \\
\text { manage their own investment. }\end{array}$ & $\begin{array}{l}\text { Singapore developed a new social } \\
\text { compact to address the challenges } \\
\text { of social mobility and social mixing. }\end{array}$ & $\begin{array}{l}\text { Japan has entered the following Bilateral } \\
\text { Investment Treaties (BITs). That makes it } \\
\text { diversified, flexible and very open to Japan FDI } \\
\text { functions. High value-added sectors (such as } \\
\text { ICT, finance, chemistry and pharmaceuticals) } \\
\text { are very well developed. }\end{array}$ \\
\hline Thailand & Pace & $\begin{array}{l}\text { Thailand still need the interdisciplinary, FDI } \\
\text { systems by Japan's DAP and creative } \\
\text { destruction activities. }\end{array}$ & $\begin{array}{l}\text { Military coups has made policymakers } \\
\text { too focused on political stability rather } \\
\text { than foreign investment. }\end{array}$ & $\begin{array}{l}\text { Japanese FDI in Thailand is increasingly } \\
\text { technology intensive, consistent with Japan's } \\
\text { aim to support the development of the next- } \\
\text { generation auto sector in Thailand. }\end{array}$ \\
\hline $\begin{array}{l}\text { Indonesia, } \\
\text { Philippines, } \\
\text { and Vietnam }\end{array}$ & Apprentice & $\begin{array}{l}\text { These countries are in the 'Apprentice' } \\
\text { phase, which is characterized by the } \\
\text { studying process of digital \& innovation } \\
\text { capability. }\end{array}$ & $\begin{array}{l}\text { Labor laws and sanctity of social } \\
\text { contract issues. Includes the economic } \\
\text { equivalent of this political conflict } \\
\text { (Except Vietnam). }\end{array}$ & $\begin{array}{l}\text { Japanese investors continuing to lead the } \\
\text { countries and territories having investment } \\
\text { projects in these countries. }\end{array}$ \\
\hline $\begin{array}{l}\text { Myanmar } \\
\text { Cambodia, } \\
\text { and Laos }\end{array}$ & Pre-incubation & $\begin{array}{l}\text { They still require to set the nation } \\
\text { infrastructures and essential institutions to } \\
\text { set up their digital \& innovation capability. }\end{array}$ & $\begin{array}{l}\text { Open and liberal foreign investment } \\
\text { regime with relatively involving a } \\
\text { concession social contract or real } \\
\text { estate development project. }\end{array}$ & $\begin{array}{l}\text { They still require to set the nation infrastructures } \\
\text { and essential institutions to set up their digital \& } \\
\text { innovation capability. }\end{array}$ \\
\hline Brunei & Unique & $\begin{array}{l}\text { Brunei has own economic model driven } \\
\text { by natural resources. }\end{array}$ & $\begin{array}{l}\text { Brunei's legal system is based on a } \\
\text { combination of British common law } \\
\text { and Indian penal code. }\end{array}$ & $\begin{array}{l}\text { Brunei is now aware of the necessity for } \\
\text { industrialization through digital \& innovation. } \\
\text { Japan has a good relationship and FDI with } \\
\text { Brunei. }\end{array}$ \\
\hline
\end{tabular}

\subsection{What are the right directions of ASEAN in DAP?}

Investments under Japan's DAP have fallen into two broad categories: (a) underlying technologies and innovation business, and (b) innovative ICT infrastructure. In order to enlarge connectivity through innovative infrastructure, Japan's alliance with other countries covers a wide range of sectors and includes technical assistance in technological industries and R\&D management. The Japan International Cooperation Agency (JICA) has used DAP to help build national infrastructure and economic development across Southeast Asia through participation in multiple development projects. These workflows are meant to support development and integrated strategies. Meanwhile, cross-border intra-regional initiatives between and among ASEAN Member States are emerging, requiring new regional coherence on promotion, regulation, financing and taxation of digital businesses. Singapore has taken a more focused approach in driving digital development and in leveraging digital convergence to create a regional hub.

It will be important to evaluate the success of DAP interventions that go beyond firm-level internal return on investment to evaluate macro-level performance indicators. Apart from Singapore, the digital economies of ASEAN countries are still under-developed, and policies, legal and institutional and regulatory frameworks vary significantly. However, Singapore, Malaysia and Thailand are already implementing inclusive strategies including development of digital industries, while others are at an earlier stage of digital development and are focusing on building digital infrastructure. The contributing of Japan's DAP and open innovation and best practices on digital development at the regional level can be useful to early-stage digitization in ASEAN member states, and can serve to attract new FDI into their respective digital economies. Regional as well as national policies are required to facilitate effective long-term sector development and economies of scale across the region. 


\section{ENTREPRENEURSHIP AND SUSTAINABILITY ISSUES}

ISSN 2345-0282 (online) http://jssidoi.org/jesi/

2020 Volume 8 Number 1 (September)

http://doi.org/10.9770/jesi.2020.8.1(72)

\section{Conclusion}

The gap between innovative and non-innovative countries in ASEAN is being well-organized by their government and private sectors. The uncertainties economic from the uncertainties politic is reflected in statistics on global FDI for the ASEAN developing countries. In the process of Japan's DAP; Cambodia, Laos, Burma, and Vietnam (CLMV) can gain short-term advantages from their capital investment. The direction view of DAP, ASEAN countries have been energetically advancing and incubating an empower environment for investment in the digital economy. The research found that ASEAN member states have been prevailing their digital and telecommunication industries, that actively promoting private investment to enhance and coverage digital economy. Other approaches include ASEAN countries' strategies that allow Japanese's FDI by attractive resourcefulness and investments in e-commerce, e-payment solutions and other areas of the innovation business. The strengthening direction of the holistic process within both the Japan's DAP and ASEAN's innovation business must be adjusted and convergence. However, ASEAN countries are adopting the concept of "innovation" and dropping it into their national policies but very often they confuse innovation with R\&D and endogenous business. As the world economic perspective is increasingly unsteady and turbulent economy. Keys to overcome those obstacles are the four elements. The first, the policymakers in ASEAN should be considered Japan's DAP as the measurement methods. The second, private sectors must be scope in the business venture capital and joint venture. The third, goalkeeper science of ASEAN member states should be connected to interdisciplinary technologies and international competitiveness. The finally, international authority and innovative infrastructure must be developed digital economy in Southeast Asia, through involvement in digital business. It is important to understand at what innovation stages and digital business capability are. Accordingly, step by step of Japan's DAP which based on effective strategic and ASEAN countries' systemic policies.

\section{Acknowledgements}

This research was partially supported by the new strategic research $(P 2 P)$ project, Walailak University, Thailand. And this paper also was partially supported by Walailak University, Thailand.

\section{References}

Ambashi, M. (2018). Economist, Innovation Policy for ASEAN. Economic Research Institute for ASEAN and East Asia (ERIA). Tokyo. Retrieved from: https://www.eria.org/5.9.ASEAN_50_Vol_5_Ambashi.pdf

Afzal, M., Mansur, K. and Manni, U. (2018). Entrepreneurial capability (EC) environment in ASEAN-05 emerging economies: An empirical approach. Asia Pacific Journal of Innovation and Entrepreneurship, 12(2), 206-221. https://doi.org/10.1108/APJIE-01-2018-0002

ASEAN Investment Report (2013). FDI Development and Regional Value Chains. United Nations Conference on Trade and Development. Jakarta. Retrieved from: https://unctad.org/en/PublicationsLibrary/unctad_asean_air2014d1.pdf

ASEAN Secretariat, UNCTAD (2017). ASEAN welcomes principles for public-private partnership framework. Retrieved from: https://asean.org/storage/2017/11/ASEAN-Investment-Report-2017.pdf

Asia-Pacific Economic Cooperation (2018). APEC Voices of the Future. Asia-Pacific Economic Cooperation Forum. Papua New Guinea. Retrieved from: http://apecvoices.org/documents/apec_papau2018_report.pdf 


\section{ENTREPRENEURSHIP AND SUSTAINABILITY ISSUES}

ISSN 2345-0282 (online) http://jssidoi.org/jesi/ 2020 Volume 8 Number 1 (September)

http://doi.org/10.9770/jesi.2020.8.1(72)

Bank of Japan (2017). Annual Report \& CSR Report for Fiscal 2017. The Bank of Japan's Organization and Business Operations. Tokyo. Retrieved from: https://www.boj.or.jp/en/about/activities/act/ar2017.htm/

Bairoch, P. (1988). Cities and Economic Development: From the Dawn of History to the Present. The University of Chicago Press. https://doi.org/10.1017/S0022050700010135

Beeson, M. (2016). Can ASEAN Cope with China? Journal of Current Southeast Asian Affairs, 35(1), 5-28. https://journals.sub.uni-hamburg.de/giga/jsaa/article/view/931/938.html

Belz, G., Wawrzynek, L., Wasowicz, M (2019). Network Potential of Innovation in Digital Transformation Projects. Transformations in Business \& Economics, 8 (2B (47B)), 694-708.

Berry, H., Guillen, M.F. and Hendi, A.S. (2014). Is there a convergence across countries? A spatial approach. Journal of International Business Studies, 45(4), 387-404. https://doi.org/10.1057/jibs.2013.72

Gallup, J.L., Mellinger, A.D. and Sachs, J.D. (1999). Geography and economic development. International Regional Science Review, 22(2), 179-232. https://doi.org/10.1177\%2F016001799761012334

Hanke, W. and Isaak, R. (2011). Brave New World Economy: Global Finance Threatens Our Future, Wiley. John Wiley \& Sons, Inc.

Hsu, J. (2017). Burmese civil society challenges China's development assistance in Myanmar. A Quarterly on Chinese Labour, Civil Society and Rights, 2(1), 44-47. https://www.chinoiresie.info/burmese-civil-society-challenges-chinas-developmentassistance-in-myanmar/

Japan Council for Science, Technology and Innovation (CSTI). (2016). Current Status on Science and Technology in ASEAN Countries, Center for Research and Development Strategy, Paper No. CRDSFY2014-OR-02-EN. Retrieved from: https://www.jst.go.jp/crds/pdf/en/CRDS-FY2014-OR-02_EN.pdf

Japan International Cooperation Agency (JICA). (2008). News: New JICA is born. The challenges ahead for Japan's development assistance. Retrieved from: https://www.jica.go.jp/english/news/field/2008/081001.html

Japan International Cooperation Agency (JICA). (2018). Annual report 2018: Thematic issues. Retrieved from: https://www.jica.go.jp/english/our_work/Thematic issues/index.html

Jarvenpaa, S. and Wernick, A. (2011). Paradoxical tensions in open innovation networks. European Journal of Innovation Management, 14(4), 521-548. https://doi.org/10.1108/14601061111174943

Kikuchi, D. and Yoshida, R. (2017). Abe confirms ¥1 trillion aid package with Duterte as Tokyo races Beijing for Manila’s support. The Japan Times. Retrieved from: https://www.japantimes.co.jp/news/2017/10/30/national/politics-diplomacy/abe-confirms

\%C2\%A51-trillion-aid-package-duterte-tokyo-races-beijing-manilas- support/\#.XjvZc2gzZPY

Limba, T., Driaunys, K., Kiskis, M. and Sidlauskas, A. (2020). Development of Digital Contents: Privacy Policy Model under the General Data Protection Regulation and User-Friendly Interface. Transformations in Business \& Economics, 19, (1(49)), $133-154$.

Malaysian Global Innovation \& Creativity Center (2019). ASEAN Startup Landscape. Policy Roundtable, GECS 2017. Retrieved from: https://mymagic.my/

Martin, R., Tyler P., Storper, M., Evenhuis, E. and Glasmeier, A. (2018). Globalization at a Critical conjuncture? Cambridge Journal of Regions, Economy and Society, 11(1), 3-16. https://doi.org/10.1093/cjres/rsy002

Manyuchi, E. A. and Mugabe, O. J. (2018). The production and use of indicators in science, technology and innovation policymaking in Africa. Journal of Science and Technology Policy Management, 9(1), 21-24. https://doi.org/10.1108/JSTPM- 06-2017-0026

Ministry of Economy, Trade and Industry (METI). (2013). Initiatives to expand foreign direct investment in Japan, Tokyo. Retrieved from: https://www.meti.go.jp/english/report/data/WP2015/3-3-2.pdf 


\section{ENTREPRENEURSHIP AND SUSTAINABILITY ISSUES}

ISSN 2345-0282 (online) http://jssidoi.org/jesi/ 2020 Volume 8 Number 1 (September)

http://doi.org/10.9770/jesi.2020.8.1(72)

Ministry of Vietnam Internal Affairs and Communications (2019). G20 trade and digital economic policy cooperation, Ho Chi Minh. Retrieved from: https://www.soumu.go.jp/english/

Munshi, A. Kasim, M. and Umme, M. (2018). Entrepreneurial capability (EC) environment in ASEAN-05 emerging economies: An empirical approach. Asia Pacific Journal of Innovation and Entrepreneurship, 12(2), 206-221. https://doi.org/10.1108/APJIE-01-2018-0002

Nanterme, P. (2016). Digital disruption has only just begun. Retrieved from: https://www.weforum.org/agenda/2016/01/digital-disruption-has-only-just-begun/

Overseas Development Institute (ODI). (2019). The production gap: 2019 report. Retrieved from: https://www.odi.org/publications/16507-production-gap-2019-report

Potts, J. (2016). Innovation policy in a global economy. Journal of Entrepreneurship and Public Policy, 5(3), 308-324. https://doi.org/10.1108/JEPP-02-2016-0003

Raghuvanshi, J. and Garg, C. (2018). Time to get into the action: Unveiling the unknown of innovation capability in Indian MSMEs. Asia Pacific Journal of Innovation and Entrepreneuship, 12(3), 279-299. https://doi.org/10.1108/APJIE-06-2018-0041

Ratna, R. and Sharma, S. (2016). Mega Trading Blocks: Is Time Ripe for ASEAN-SAARC FTA? South Asia Economic Journal, 17(2), 181-199. https://doi.org/10.1177\%2F1391561416649723

Sako Koji (2018). Japan's foreign direct investment trends in Asia. Mizuho Economic Outlook \& Analysis. Retrieved from: https://www.mizuho-ri.co.jp/publication/research/pdf/eo/MEA181218.pdf

Sahadev, S. and Hoontrakul, P. (2015). Developing ASEAN India partnership for fostering technology development. Journal of Indian Business Research, 7(2), 205-218. https://doi.org/10.1108/JIBR-10-2014-0069

Shimato, H. (2018). Leading companies in ASEAN. Strategic Planning Dept., Planning Div. Mitsui \& Co. (Asia Pacific) Pte. Ltd. Retrieved from: https://www.mitsui.com/mgssi/en/report/detail/__icsFiles/afieldfile/2019/08/13/1907c_fukuoka_e_1.pdf

Sukma, R. and Soeya, Y. (2015). Navigating change: ASEAN-Japan strategic partnership in East Asia and in global governance. Japan Center for International Exchange (JCIE), Tokyo. Retrieved from: http://www.jcie.or.jp/books/abstracts/N/navigatingchange.html

The Government of Japan (2019). ASEAN-Japan Comprehensive Economic Partnership Agreement, Tokyo. Retrieved from: https://www.mofa.go.jp/policy/economy/fta/asean.html

Tor, W. Andreassen., Line, L. Olsem., Hannah, S., Allard, C.R. Vanriel., Jillian, C. Sweeney. and Yves, V. Varenbergh (2018). Business model innovation and value-creation: the triadic way. Journal of Service Management, 29(5), 883-906. https://doi.org/10.1108/JOSM-05-2018-0125

Trinidad, D. (2018), What Does Strategic Partnerships with ASEAN Mean for Japan's Foreign Aid? Journal of Asian Security and International Affairs, 5(3), 267 - 294. https://doi.org/10.1177\%2F2347797018798996

Uhm, C., Sung, C. and Park, J. (2018). Understanding the accelerator from resources-based perspective. Asia Pacific Journal of Innovation and Entrepreneurship, 12(3), 258-278. https://doi.org/10.1108/APJIE-01-2018-0001

United Nations Conference on Trade and Development (UNCTAD). (2018). Foreign Direct Investment and the Digital Economy in ASEAN 2018, Geneva. Retrieved from: https://unctad.org/en/PublicationsLibrary/unctad_asean_air2018d1.pdf

Windahl, C. (2015). Understanding solutions as technology-driven business innovations. Journal of Business \& Industrial Marketing, 30(3/4), 378-393. https://doi.org/10.1108/JBIM-11-2013-0253

World Economic Forum (2017). The global competitiveness report 2017-2018. World Economic Forum, Geneva. Retrieved from: https://www.weforum.org/reports/the-global-competitiveness-report-2017-2018 


\title{
ENTREPRENEURSHIP AND SUSTAINABILITY ISSUES
}

ISSN 2345-0282 (online) http://jssidoi.org/jesi/ 2020 Volume 8 Number 1 (September) http://doi.org/10.9770/jesi.2020.8.1(72)

World Economic Forum (2019). The global competitiveness report 2019. World Economic Forum, Geneva. Retrieved from: https://www.weforum.org/reports/global-competitiveness-report-2019

Yoshimatsu, H. (2017). Japan's export of infrastructure systems: Pursuing twin goals through developmental Means. The Pacific Review, 30(4), 494-512. https://doi.org/10.1080/09512748.2016.1276953

Yukawa, T. (2018). European integration through the eyes of ASEAN: Rethinking Eurocentrism in comparative regionalism. International Area Studies Review, 21(4), 323-339. https://doi.org/10.1177\%2F2233865918808035

\begin{abstract}
About Authors
Somnuk AUJIRAPONGPAN, Ph.D., is an associate professor in accounting and director of graduate study in innovation management and business development, School of Management, Walailak University, Thailand. He received his Ph.D. in technopreneurship and innovation management from Chulalongkorn University. His professional expertises are managerial accounting, cost accounting, knowledge management, innovation management and entrepreneurship development. His publications have appeared in various national and international academic journals about managerial accounting, entrepreneurship and business management. He also is a corresponding author of this article who provides the intellectual input, designs and approves the protocols to be followed in the study.
\end{abstract}

ORCID ID: orcid.org/0000-0001-6275-9053

Yaninee SONGKAJORN, Ph.D., is a lecturer in Graduate Study in Innovation Management and Business Development, School of Management, Walailak University, Thailand. She received her Ph.D. in technopreneurship and innovation management from Chulalongkorn University. Her publications have appeared in various national and international academic journals about technology management, innovation management and entrepreneurship development.

ORCID ID: orcid.org/0000-0002-0474-4619

Supit RITKAEW, Ph.D., is an assistant professor in applied mathematics of Innovation Management and Business Development Graduate Study Program of Walailak University. He received his Ph.D. in applied mathematics from University of Innsbruck, Austria. His professional expertises are business analytics, statistics and forecasting. And his publications also have appeared in various national academic journals about business analytics and entrepreneurship.

ORCID ID: orcid.org/0000-0003-0543-7730

Sirichai DEELERS, Ph.D., is an assistant professor in management of Faculty of Management Science, Silpakorn University, Thailand. He received his Ph.D. in management from Silpakorn University. His publications have appeared in various national academic journals about innovation management, business administration and information management.

ORCID ID: orcid.org/0000-0002-6521-1795

Make your research more visible, join the Twitter account of ENTREPRENEURSHIP AND SUSTAINABILITY ISSUES: @Entrepr69728810

Copyright (C) 2020 by author(s) and VsI Entrepreneurship and Sustainability Center

This work is licensed under the Creative Commons Attribution International License (CC BY).

http://creativecommons.org/licenses/by/4.0/

(c) (i) Open Access 